\title{
Direct Democracy Beyond the Logic of Archēe
}

\section{Democracia directa más allá de la lógica del archē}

\author{
ANAT ASCHER \\ Department of Philosophy, Tel Aviv University, Israel
}

\begin{abstract}
This article explores the political challenges posed by direct democracy. A consideration of Locke's political thought reveals representative democracy to be nothing more than a compromise meant to maintain an economic structure of laisser-faire, while a Rousseauistic direct democracy that demands homogeneity turns out to be not much of a democracy either. The question at hand is whether there can be a political regime in which both all-inclusive participation in the political realm and an actual diversity of the participants exist. Two different answers to this question are presented through the writings of Jean-Luc Nancy and Jacques Rancière.

KEYWORDS

DIRECT DEMOCRACY, LOCKE, NANCY, RANCIÈRE, REPRESENTATIVE DEMOCRACY, ROUSSEAU
\end{abstract}

\section{RESUMEN}

El presente artículo explora los retos políticos que plantea la democracia directa. En el pensamiento político de Locke la democracia representativa consiste en el compromiso de-mantener la estructura económica de laisser-faire, mientras que la democracia directa rousseauniana que demanda homogeneidad acaba por no ser muy democrática. La cuestión en juego es si puede haber un régimen político capaz de acoger tanto una participación inclusiva como la diversidad existente de los participantes. Se presentan dos respuestas diferentes a esta pregunta a través de las obras de Jean-Luc Nancy y Jacques Rancière.

1 The author would like to thank Rosario López, Marta Postigo, Kari Palonen, Zvi Tauber, Yoni Ascher, and Itay Snir for their thought-provoking remarks on earlier versions of this text.

(C) Contrastes. Revista Internacional de Filosofia. Suplemento 20 (2015), pp. 61-75. ISSN: 1136-9922

Departamento de Filosofía, Universiad de Málaga, Facultad de Filosofía y Letras

Campus de Teatinos, E-29071 Málaga (España) 


\section{PALABRAS CLAVE \\ DEMOCRACIA DIRECTA, DEMOCRACIA REPRESENTATIVA, LOCKE, NANCY, RANCIÈRE, ROUSSEAU}

\section{INTRODUCTION}

Democracy, as we all know, originated in ancient Greece, where the people of Athens overthrew a dynasty of tyrannical rulers and established a government of the people in their stead. So democracy, originally, was a direct form of government, one in which the people had an active role in the polis's decisionmaking processes. In the modern era, however, the term democracy is used to describe two forms of governance (to put it extremely simplistically for the moment): a direct democracy or a representative one, with the latter form being much more common in our times. In recent years, several social phenomena, most having to do with new possibilities enabled by novel technology, bring our political reality back to the prospect of direct democracy, not as a political utopia (as it often was in centuries past), but rather as a viable option that, at the very least, demands our critical attention.

Adherents of direct democracy often claim that this is the only true form of democracy, whereas representative democracy is nothing but a compromise meant to serve external and mostly economic interests. If we take democracy to be the government of the people, then using this precious authority only to immediately relegate the governing role to a small and limited group within society seems like somewhat of a missed opportunity. And if this is not considered a missed opportunity, it is probably because the prospect of participating in the governance of the state was not the essence of this political structure to begin with. In an attempt to consider the rationale that underlies the political system of representative democracy, it is perhaps best to go back to one of the founding fathers of the liberal tradition of thought, John Locke, and consider how political power is constituted and legitimated in his philosophical account. ${ }^{2}$

2 Although the term «democracy» does not strictly apply to Locke's own thought, his ideas undoubtedly constitute the origin of a sequence of political accounts resulting in variant forms of representative democracy: «If Hobbes has the honour of being the first to articulate the philosophical basis of liberalism, Locke must be credited with first formulating the basic structure of liberal democracy». B. Parekh, «The Cultural Particularity of Liberal Democracy» in Political Studies. Vol. 40 (1) (1992): 160-175, 165. Emphasis in original. 


\section{THE COMPROMISE OF REPRESENTATIVE DEMOCRACY}

Locke wrote his Two Treatises on Government less than forty years after Hobbes's Leviathan was published, yet his theories differ significantly from his countryman's political ideas. ${ }^{3}$ According to Hobbes's account, men gather into political alliances in order to cease the ongoing war of all against all, which is the only possible outcome of the state of nature. A sovereign is thus chosen in order to put an end to this unfortunate state of affairs and to bring a sense of security and stability to people's lives. Leaving the state of nature and entering into political society entails, therefore, that all men should abandon the conduct that characterized the state of nature, namely that they resign their natural right to the chosen sovereign, whose power then becomes absolute. The natural right that is relinquished in Hobbes's account is the liberty, which everyone enjoyed in the state of nature, to take care of oneself and to ensure one's own preservation by whatever means necessary. ${ }^{4}$ This right is considered natural not only because it is part of the state of nature, but primarily as it stems from man's nature. This is because in Hobbes's materialist thought, that which is called «the passions of the soul» is actually the result of our physiological state. In other words, the preferable condition of the body -the absence of pain and the experience of pleasure- becomes the impetus for all human behavior. And so, it is in man's nature to avoid pain and to seek pleasure, and his search for pleasure tends to lead him to the aforementioned state of ongoing combat in which he has the right to protect himself in whatever way he sees fit.

In contrast to Hobbes's account and his relentless support of an absolute sovereign, Locke presents his own understanding of the state of nature and the desired form of a political regime. The primary liberty in the state of nature, he claims, does not necessitate such recklessness as in Hobbes's account. On the contrary, according to Locke,

3 The relations between these two political accounts have been quite a point of contention among researchers. Some have suggested that Locke's account has specifically targeted Hobbes's absolutist notions (see, for instance, C.L. Becker, The Declaration of Independence: A Study in the History of Political Ideas. New York: Harcourt, Brace, 1922, 70; T.D. Weldon, The Vocabulary of Politics. Harmondsworth, UK: Penguin, 1953, 39-40). Others insisted that Locke must not be read side by side with Hobbes (see, for example, J. Dunn, The Political Thought of John Locke: An Historical Account of the Argument of the Two Treatises of Government. Cambridge: Cambridge University Press, 1969, 77; P. Laslett, «Preface», in Locke, J. Two Treatises of Government and A Letter Concerning Toleration. New Haven and London: Yale University Press, 2003, x). Resolving this dispute is far beyond the scope of this article; however, for my own purposes the relevant issue at hand is the actual difference between Hobbesian and Lockean thought, regardless of whether it results from an unintentional or a deliberate act.

4 T. Hobbes, Leviathan. Oxford: Oxford University Press, 1998, 106. 
But though this be a State of Liberty, yet it is not a State of Licence, though Man in that State have an uncontrollable liberty, to dispose of his Person or Possessions, yet he has not Liberty to destroy himself, or so much as any Creature in his possession [...] The State of Nature has a Law of Nature to govern it, which obliges every one: And Reason, which is that Law, teaches all Mankind, who will but consult it, that being all equal and independent, no one ought to harm another in his Life, Health, Liberty, or Possessions. For men being all the Workmanship of one Omnipotent and infinitely wise Maker; all the servants of one Sovereign Master, sent into the World by his order, and about his business, they are his Property, whose Workmanship they are, made to last during his, not one anothers pleasure. ${ }^{5}$

Locke tells us that the law of nature in the state of nature regulates human behavior prior to the existence of any written law. This law of nature is the voice of reason, and yet it is also the will of God. This somewhat peculiar duality is resolved as follows: as all creatures were made by God, and all that they have they were given by him, it follows that all of them are put on this earth for his pleasure and function as his property. Harming one another, or even oneself for that matter, is equivalent to damaging God's possessions, and it is quite easy to understand how this would not be a particularly recommended course of action. Another interesting idea is derived from this major line of argument: the natural rights mentioned - the rights to life, health, liberty, and possessions- are perhaps natural in the sense that they exist in the state of nature, but in no way do they stem from man's nature. Rather, they are given to him by his creator as goods; they are his assets. Thus it can be argued that Locke's account shows early on that what makes human beings what they are (and is thus essential for them), that which sets them apart from all other creatures, from the rest of God's creation, is something they are given, i.e. the initial goods they come to possess.

As can be expected, the natural rights, namely the assets men receive from God in the state of nature, are to be found at the heart of Locke's desired political regime. That is to say, protecting these rights and ensuring the ability to enjoy them is the end goal of any legitimate political gathering.

[T]hough in the state of Nature [man] hath such a right, yet the Enjoyment of it is very uncertain, and constantly exposed to the Invasion of others [...] This makes him willing to quit this Condition, which however free, is full of fears and continual dangers: And 'tis not without reason, that he seeks out, and is willing

5 J. Locke, «The Second Treatise of Government», in Two Treatises of Government. Cambridge: Cambridge University Press, 1988, 270-271 (§6). 
to joyn in Society with others who are already united, or have a mind to unite for the mutual Preservation of their Lives, Liberties, and Estates, which I call by the general name, Property. The great and chief end therefore, of Mens uniting into Commonwealths, and putting themselves under Government, is the Preservation of their Property. ${ }^{6}$

The rationality of engaging in a political regime, which necessarily diminishes human liberty to a certain extent, results from the desire to protect the property men already possess in the state of nature. This property, to be sure, is composed not only of material goods and estates men have earned through their labor, but also from their rights to life and liberty, which they received from their Maker. The entire threesome - life, liberty, and estates- form together the property that needs be protected by the mechanisms of the state. However, a closer look discloses a slightly preferential position to one factor in this threesome. While arguing against the legitimacy of any political regime to act arbitrarily, Locke draws a comparison between two forms of absolute power: that of the state and that of martial discipline. Insisting that in order to be just, even absolute power has to abide by reason, he argues:

[N]either the Serjeant, that could command a Soldier to march up to the mouth of a Cannon, or stand in a Breach, where he is almost sure to perish, can command that Soldier to give him one penny of his Money; nor the General, that can condemn him to Death for deserting his Post, or for not obeying the most desperate Orders, can yet with all his absolute Power of Life and Death, dispose of one Farthing of that Soldier's Estate, or seize one jot of his Goods. ${ }^{7}$

Even within a justifiable political regime, it is clearly stated that the preservation of the right to life has its own exceptions. However, even in the most extreme situation, one right that remains untouchable is men's material goods. The right to accumulate wealth, therefore, is presented almost as a sacred element, as the highest entitlement of all, and the one that should be uncompromisingly protected and cherished. Locke's discussion of the right to possess assets reveals something about his notion of liberty as well. The liberty man has in the state of nature, and the liberty that should eventually be protected by the state, is the liberty to conduct one's affairs unhindered with nothing that might stand in the way. This sort of liberty, it is important to note, has nothing to do

6 Ibid., 350-351 (§123-4).

7 Ibid., 362 (§139). 
with the right to be involved in public matters; quite the opposite, it has to do with broadening the private sphere as much as possible, that is to say in living one's life -and obtaining one's material goods- unobstructed.

Up to this point, Locke's arguments have shown us that the desirable political regime, according to his point of view, should defend men's ability to enjoy their property. It has also been demonstrated that in order to do so, the regime must rely on an accepted set of laws, an agreed upon constitution that will prevent any chance of arbitrariness on the part of the government. What has yet to be answered, however, is what kind of political regime will best suit these requirements. Can it be obtained in the form of a monarchy (as in Hobbes's account), or does it necessitate spreading sovereignty among a greater populace? Locke's answer is as follows:

Though in a Constituted Commonwealth, [...] there can be but one Supreme Power, which is the Legislative, to which all the rest are and must be subordinate, yet the Legislative being only a Fiduciary Power to act for certain ends, there remains still in the People a Supreme Power to remove or alter the Legislative, when they find the Legislative act contrary to the trust reposed in them [...] And thus the Community perpetually retains a Supreme Power of saving themselves from the attempts and designs of any Body, even of their Legislators, whenever they shall be so foolish, or so wicked, as to lay and carry on designs against the Liberties and Properties of the Subject. ${ }^{8}$

According to Locke, political power should remain in the hands of the people. This is because there is always a possibility of legislative authority going astray. When such is the case, the people should have the power to remove the legislator from office in order to protect themselves, or more specifically to protect their property. And so, in Locke's account, though the sovereign is ultimately the people, it can be argued that the sovereignty remains with the people as a precaution, in case some legislator decides to interfere with their property, that is, to invade their private space.

To sum up Locke's position, the political system portrayed in his writings rests on his notion of liberty. If liberty is taken to be the right to manage one's own affairs undisturbed, it follows that the sovereignty should remain with the people, so they can protect their liberty. However, it also requires that in order to fully realize this liberty the people must appoint representatives, rulers to relieve them of the burden of conducting public matters. The representatives

8 Ibid., 366-367 (§149). 
are appointed to leave the people with as much freedom as possible, freedom to pursue their private interests. The greater good, in this form of a political gathering, is the accumulation of the individual successes of the people. It turns out, thus, that according to Locke's liberal line of reasoning, the incentive to form the sort of political establishment known today as representative democracy is an economic one, strictly speaking, namely the desire to be able to peacefully accumulate fortune and advance oneself. The democratic form in this case is nothing more than a necessity, and by all means not an end in itself. A similar realization is lucidly articulated in a statement made by a later liberal thinker -Alexis de Tocqueville:

I accept the intellectual rationale for democratic institutions, but I am instinctively an aristocrat, in the sense that I contemn and fear the crowd. I dearly love liberty and respect for rights, but not democracy. ${ }^{9}$

\section{DIRECT DEMOCRACY AND THE DEMAND FOR UNIVOCACY}

The immanent pretense in representative democracy was clear not only to Tocqueville, the liberal who still supported it, but also to one of the most interesting critics of liberal thought -Jean-Jacques Rousseau- ${ }^{10}$ In what has come to be known as one of the most important and influential political texts of the eighteenth century, «On the Social Contract», he writes:

As soon as public service ceases to be the main business of the Citizens, and they prefer to serve with their pocketbooks rather than with their persons, the State is already close to its ruin [...] It is involvement in commerce and the arts, avid interest in profits, and softness and love of comforts that replace personal services by money. One gives up part of his profit in order to increase it at leisure. Give money and you will soon have chains. ${ }^{11}$

9 A. Tocqueville, New York Daily Tribune. June 25, 1853.

10 For some recent writing on Rousseau's critique of liberalism, see: C. Orwin, «Rousseau Between Two Liberalisms: His Critique of the Older Liberalism and His Contribution to the Newer One», In Espada, J.C., Plattner, M.F., and Wolfson, A. (Eds.), The Liberal Tradition in Focus. Lanham, Maryland: Lexington Books, 2000, 53-65; J. Marks, Perfection and Disharmony in the Thought of Jean-Jacques Rousseau. Cambridge: Cambridge University Press, 2005, 149-157; J.R. Reisert, Jean-Jacques Rousseau: A Friend of Virtue. Ithaca, New York: Cornell University Press, 2003, 185-196.

11 J.J. Rousseau, «On the Social Contract», in The Collected Writings of Rousseau, Vol. 4. 
Rousseau clearly acknowledges the rationality that rests in the foundations of the liberal system of representative democracy, and pinpoints the fact that it is above all a financial interest that is the core of this political structure. However, while Locke, a keen supporter of this structure, views it as the ultimate manifestation of human liberty, that which Locke considers liberty -the liberty of every person to accumulate great fortune- Rousseau believes to be quite the opposite.

What man loses by the social contract is his natural freedom and an unlimited right to everything that tempts him and that he can get; what he gains is civil freedom and the proprietorship of everything he possesses [...] To the foregoing acquisitions of the civil state could be added moral freedom, which alone makes man truly the master of himself. For the impulse of appetite alone is slavery, and obedience to the law one has prescribed for oneself is freedom. ${ }^{12}$

In fact, Rousseau ascribes to man a similar kind of liberty in the state of nature as introduced by Locke. When describing human existence prior to the creation of society, he portrays man as a creature whose freedom is manifested in the fact that he can sustain himself on his own, uninterrupted by others. This kind of liberty, however, is soon declared by Rousseau to be slavery in disguise. In this situation man is enslaved by his instinctive desires, so to speak, as he is only free to choose the preferable means to the ends dictated by those desires. It is solely through being able to choose the ends themselves that real freedom can be realized. To be able to do so, man has to cooperate with others, which means to forego his natural and individualistic liberty and replace it with civil and communitarian liberty that will allow him to be part of an autonomous body politic. The understanding of true liberty as the ability to be autonomous also clarifies why, in Rousseau's account, the act of legislation is never to be handed over to someone else. Giving up the right to enact laws -which is also a civil duty-and appointing a representative to do it amounts to losing autonomy, which is the only real form of freedom.

Rousseau's critique seeks to expose liberal representative democracy for what he takes it to truly be -enslavement to the hoarding of goods- and to present in its stead an appropriate form of democracy based upon autonomy, a direct democracy in which the people are genuinely engaged in the act of shaping the form of their common existence. This substitutive form of democracy,

Tr. J.R. Bush, R.D. Masters and C. Kelly. Hanover: Dartmouth College Press, 1994, 191-192.

12 Ibid., 141-142. 
however, brings with it a whole new set of difficulties, the greatest of which has to do with the measure of liberty this political system actually tolerates. According to Rousseau, in order for a people to be truly autonomous, to be able to legislate together laws that will ensure the good of the community, they should be as homogenous as possible in their decision-making:

It can be seen [...] that the way in which general matters are handled can provide a rather precise indication of the current state of the morals and health of the body politic. The more harmony there is in the assemblies, that is, the closer opinions come to obtaining unanimous support, the more dominant as well is the general will. But long debates, dissensions, and tumult indicate the ascendance of private interests and the decline of the State. ${ }^{13}$

In Rousseau's view, this demand for unanimity is conditional for the regime's stability. Simultaneously, it is a result of the divided image he holds regarding the human psyche. For Rousseau, there can be either private will or general will; the former is concerned with the individual's private interests, the latter aims at the bigger picture and takes into consideration the well-being of the entire community. Private will is the trace of natural liberty men possessed prior to the establishment of the state. Thus, along with the supposed renunciation of natural liberty, it should have been relinquished as well. But in fact, men tend to hold on to their natural liberty and consequently to their private will. In Locke's account, the human tendency to cling to private interests posed no political problem. On the contrary, this is precisely what men are supposed to do in order for society to flourish, since the greater good is understood as the accumulation of the individuals' accomplishments. In Rousseau's view, however, the good of the community has its own independent existence and should be deduced on its own. It is for this reason that he claims that when public deliberation tends to be in accord, it is a strong indication that the general will is the dominant one. The closer we get to unanimity, the greater grounds we have to believe that people have embraced the interests of the community as their own, that they have become able and willing to identify themselves and their interests with the whole of the community. ${ }^{14} \mathrm{But}$

13 Ibid., 199.

14 For this reason, many of Rousseau's commentators over the years have tended to emphasize the totalitarian aspects of his political account. See, for example H.A. Taine, The Origins of Contemporary France: The Ancient Regime, the Revolution, the Modern Regime. Selected Chapters. Chicago: University of Chicago Press, 1974, 272; J.L. Talmon, The Origins of Totalitarian Democracy. New York: F. A. Praeger, 1965, 43; L.G. Crocker, Rousseau's Social Contract: An Interpretive Essay. Cleveland: Press of Case Western Reserve University, 1968, 163. 
how can this homogeneity, or unanimity, be achieved if the whole purpose of the desired political structure is to manifest the people's liberty? How can people be expected to not merely go against their basic instincts, but to do so freely?

Rousseau's answer to these quandaries is through the acts performed by the «legislator». An outsider to the body politic itself, the legislator draws his authority through his charismatic character, as if he were a messenger of God. He is the one entrusted with the role of changing the nature of all members of society and bringing them to embrace moral liberty at the expense of their former, natural liberty:

One who dares to undertake the founding of a people should feel that he is capable of changing human nature, so to speak [...] He must, in short, take away man's own forces in order to give him forces that are foreign to him and that he cannot make use of without the help of others. The more these natural forces are dead and destroyed, and the acquired ones great and lasting, the more the new institution as well is solid and perfect. ${ }^{15}$

The laws decreed by the legislator are supposed to gradually work their way into people's hearts, eventually getting them to abandon their private wills and to adopt the general will as their sole disposition. And so, it is only once the right laws have trained the human psyche to be socially-oriented as its default that people can be completely trusted with the responsibility of autonomy, of shaping their shared existence together through legislation. Although the laws of the legislator should resolve the obstacle posed by any stubborn individualism that still persists within the state, it is still unclear why the members of society should accept his laws in the first place, unless they are coerced to do so. Addressing this difficulty, Rousseau proposes the following:

This is what has always forced the fathers of nations to have recourse to the intervention of heaven and to honor the Gods with their own wisdom; so that the peoples $[\ldots]$ might obey with freedom and bear with docility the yoke of public felicity. It is this sublime reason [...] whose decisions the legislator places in the mouth of the immortals in order to win over by divine authority those who cannot be moved by human prudence. ${ }^{16}$

15 Rousseau, «On the Social Contract», 155.

16 Ibid., 156-157. 
The legislator, it turns out, disguises his own wisdom as a divine commandment. In doing so, he elevates the contingent laws of his own making to the level of necessity possessed by the laws of nature. And since one cannot but obey that which is necessary, the people obeying the statutes of the legislator are «freely obeying» them. ${ }^{17}$ In other words, in order to maintain a free consciousness amid the people, Rousseau's legislator has to manipulate them to believe that they are freely accepting his laws, laws that should, in time, transform their nature. However, one cannot but wonder as to the measure of freedom such a misled consciousness in fact possesses. It is Rousseau himself who vigorously asserts that one of the vital conditions for being autonomous is being well-informed prior to any decision-making. And so, according to Rousseau's own definitions, the conditions required to produce a stable autonomous regime prevent it from being thoroughly autonomous.

We are left, at this point, with two different models of democratic regimes, neither of which is as democratic as it professes to be. Locke's account uses democratic self-sovereignty only as a compromise meant to ensure the continuation of a capitalist economy. It is perfectly clear to him that the people should not be in charge of shaping the state's character through legislation; rather they should leave the act of lawmaking to professional rulers and invest their efforts in working and increasing their wealth. Keeping the sovereignty with the people is thus nothing more than a precaution against unwelcome interference with the political-economic order of laisser-faire. Rousseau's proposed regime indeed gives more power to the people to really shape their society by means of lawgiving. But in order to do so, he finds it necessary to first shape the spirit and tendencies of the people. Thus, in order to achieve an autonomous regime of self-sovereignty in which the people actually take part in the act of ruling, he resorts to indoctrination and manipulation.

Not presented explicitly, it can nevertheless be argued that the point of contention between these two philosophical accounts is the place allocated to individuality. While in Locke's account individuality is elevated to the point of disrupting any chance of a formation of «a people», in Rousseau's account individuality is effectively eradicated in order to secure the regime's stability and its possibility to articulate the good of the community in its legislation. This

17 For an illuminating analysis of the problematic nature of Rousseau's legislator, see C. Kelly, «To Persuade without Convincing: The Language of Rousseau's Legislator», in American Journal of Political Science. May, Vol. 31 (2) (1987), 321-335. The God-like character of the legislator and its implications on Rousseau's political thought has been recently discussed by Simon Critchley. See S. Critchley, «The Catechism of the Citizen: Politics, Law and Religion in, after, with and against Rousseau» in Continental Philosophy Review. Vol. 42 (1) (2009), 5-34. 
raises the question of whether there can be a form of democracy that will allow for both diversity and participation. The challenge posed by this problematization was taken up most intriguingly in some recent political accounts, two of which are offered by Jean-Luc Nancy and Jacques Rancière.

\section{BEYOND THE LOGIC OF $A R C H \bar{E}$}

Nancy's answer to the proposed question is in essence positive, but complex. Namely, he believes in the feasibility of a form of democracy that will allow for both diversity and participation. This stance has to do with Nancy's understanding of the basic character of human existence. For him, the most basic trait of human existence is the fact of being in common. This is prior, claims Nancy, to any other characteristic of existence and even to any organizing principle, any arche ( $\square \rho \chi \eta$ ) to the community. This does not mean, of course, that an organizing principle, a «first cause» or an «ultimate end», will not make its appearance at some point. But the possibility of a boundless existence is nonetheless a viable one. This, in fact, is precisely the meaning of democracy.

Democracy is a combination of two root words, the second of which (-cracy) refers to force and violent imposition, unlike the root-archy, which relates to power that is grounded, legitimated by some principle [...] [T]he word democracy seems to contain an internal barrier to the possibility of a foundational principle [...] Democracy, as a species to the genus politics, is incapable of being grounded in a transcendent principle. So the only thing that grounds or founds democracy is an absence: the absence of any human nature. ${ }^{18}$

Being derived from the root -cracy and not -archy (which implies the existence of an $\operatorname{arche}$ ), democracy is in its very essence a gathering with no prior grounding principle, no definition and no objective. For this reason it allows variety and multiplicity to manifest themselves without trying to force them into homogeneity or uniformity of any kind. It is a political form in which community is established through acceptance of human diversity:

18 J. L. Nancy, «Finite and Infinite Democracy», in Giorgio Agamben, et al. Democracy in what s State? Tr. W. McCuaig. New York: Columbia University Press, 2011, 65-66. Emphasis in original. 
All that we can know boils down to two propositions: our existence is without any prior design, destiny, or project; and it is neither individual nor collective, since existence, the truth of «being», is something that only comes about within the plurality of individuals into which dissolves any postulate of the unity of «being» [...] What «democracy» signifies here is the admission -without any heavenly assumption- of all these diversities to a «community» which does not unify them, but, on the contrary, deploys their multiplicity, and with it the infinite of which they constitute the numberless and unfinalizable forms. ${ }^{19}$

Interestingly, Nancy's conceptualization of democracy does not put the emphasis on a concrete configuration of government, but on the temperament of common human existence. For this reason, in his view the rule of the people is not so much a specific form of government, as it is a basic disposition of people towards one another and towards sharing their lives together, a disposition of mutual expectance, rather than subordination or exclusion.

In this respect, democracy is a description and/or an evaluation of a being in common founded upon the mutual recognition of fellows [semblables] and upon the independence of each group wherein this recognition is shared. ${ }^{20}$

Now the reason why this is so important for Nancy is that this notion of democracy presents a way out of the theologico-political argumentation so characteristic of Western political thought, toward a form of political existence truly liberated from the logic of arche. This is because only when nothing is predefined is there a genuine possibility that every form of human existence will be accepted as is, creating a political reality of both variety and partaking. And it is this sort of communal existence that can be justifiably called emancipated, being open to infinite possibilities.

Democracy $[\ldots]$ is the appellation, the utterly inadequate appellation, of a humanity that finds itself exposed to the absence of any given end -a heaven, a future- but not less exposed to the infinite for that. Exposed, existing. ${ }^{21}$

19 Ibid., 71-72.

20 J. L. Nancy, The Truth of Democracy. Tr. P.A. Brault and M. Naas. New York: Fordham University Press, 2010, 39.

21 Nancy, «Finite and Infinite Democracy», 75. Emphasis in original. 
But can such emancipated existence truly persist? Can there be a longlasting community without any organizing principle? Locke and Rousseau, early modern thinkers, did not entertain such a possibility. Both of them grounded their proposed societies according to some principle. Remarkably, they both resorted to religion, either with genuine conviction or purely strategically, in order to reinforce this principle. Nancy's account, secular in its very essence, is able to contemplate the possibility of truly ungrounded human existence.

Rancière's answer to this query, however, is different. According to him, shared existence is always founded upon what he calls a «distribution of the sensible». The distribution of the sensible is what makes possible the formation of a sphere of shared meanings, by arranging our perceived reality and putting it in a particular order. It calls for the identification of certain positions and functions in society, and points towards the proper ways of fulfilling them in practice; it allocates specific roles to the various groups within society, and determines the use of communicative vehicles. In other words, the distribution of the sensible defines the legitimate ways to partake in society. Thus, this distribution is twofold by its very nature, excluding just as much as it is including: in order to define the manner in which we interpret our perceived reality, it also has to define the boundaries of this reality, namely what is included in it and what is excluded from it.

Political regime, what Rancière calls the "police», is the way in which the allocation of roles and positions within society, and the power that comes along with it to ensure its proper functioning, are legitimated. In this respect the regime is an order that defines «the visible and the sayable», that is, a system that guarantees that a particular way of conduct is commensurable and another is incommensurable. In this sense, at the core of every political regime, according to Rancière, a certain distribution of the sensible is always to be found. Because the distribution of the sensible is in fact an organizing principle, it can be easily deduced that in Rancière's account, the possibility of a political regime with no organizing principle is null and void. This, however, is certainly not the case with regard to political action. Contrary to a political regime, political action challenges the prevailing police. It is a polemic encounter, one that is always at odds with the existing regime: if carried out successfully, political action forces a change upon the existing regime, either by tampering with its inner structure or by shattering its former boundaries. This is achieved by way of heterogeneous participation in the existing regime, by claiming «the part of those who have no part» in it, the count of the unaccounted-for (le compte des incomptés). This controversial partaking that constitutes political action is, according to Rancière, the true meaning of democracy. 
Democracy is not a political regime. Insofar as it is a rupture in the logic of arche -that is, in the anticipation of rule in the disposition for it- democracy is the regime of politics $[\ldots]$ The «freedom» of a people that constitutes the axiom of democracy has as its real content the rupture of the axioms of domination: A rupture, that is, in the correlation between a capacity for rule and a capacity for being ruled [...] Democracy is thus precisely not a political regime in the sense of a particular constitution that determines different ways of assembling people under a common authority. Democracy is the institution of politics - the institution of both its subject and its mode of relating-. ${ }^{22}$

The reason why, in Rancière's account, democracy is not a form of political regime but rather a form of political action is that the moment of political action -of participation on the part of those who usually have no part in society- is the only moment in which a demos manifest itself. Moreover, in this action, in which the limiting and excluding logic of archē is transgressed, the people take hold of shaping their future society. Dispensing momentarily with the logic of domination, a fundamental human equality is put forward and enables everyone to be present, to participate in the political realm. However, this is not a permanent state. It is an action, and thus an ephemeral episode. And once the political action is concluded, whether successful or not, we are left with a regime, in which a distribution of the sensible -i.e. an organizing principle-is always to be found.

We started by suggesting that direct democracy is the only true form of democracy, that is to say, the only form of democracy in which the demos is an end in itself. We have shown that once direct democracy is understood as a political form that demands homogeneity in order to secure its resilience, there is not much democracy in fact left. We concluded with an attempt to understand democracy as a form of existence that goes beyond any organizing principle, thus enabling a reality in which participation can coexist with diversity. Finally, since none of the thinkers whose accounts were examined here treated democracy as a form of political regime, but rather as a certain disposition or as an action, we come to wonder whether this can really become a form of ongoing human existence, or will it always remain in the form of momentary occurrences. It is often said of our times that we live in a state of permanent revolution; perhaps it is therefore our task to find ways of transforming the democratic moments of political action to a long-lasting form of existence beyond any logic of arche .

22 J. Rancière, «Ten Theses on Politics», Tr. R. Bowlby and D. Panagia. Theory \& Event. Vol. 5, 3, (2001): URL: http://muse.jhu.edu/journals/theory_and_event/toc/tae5.3.html. 
